University of Nebraska - Lincoln

DigitalCommons@University of Nebraska - Lincoln

USDA Wildlife Services - Staff Publications

U.S. Department of Agriculture: Animal and Plant Health Inspection Service

$10-1-2021$

\title{
Satellite-detected ammonia changes in the United States: Natural or anthropogenic impacts
}

\author{
Yaqian $\mathrm{He}$ \\ University of Central Arkansas, xuro@oregonstate.edu \\ Rongting Xu \\ Oregon State University \\ Stephen A. Prior \\ USDA Agricultural Research Service \\ Di Yang \\ University of Wyoming \\ Anni Yang \\ Colorado State University
}

Follow this and additional works at: https://digitalcommons.unl.edu/icwdm_usdanwrc

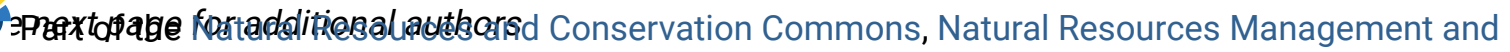
Policy Commons, Other Environmental Sciences Commons, Other Veterinary Medicine Commons, Population Biology Commons, Terrestrial and Aquatic Ecology Commons, Veterinary Infectious Diseases Commons, Veterinary Microbiology and Immunobiology Commons, Veterinary Preventive Medicine, Epidemiology, and Public Health Commons, and the Zoology Commons

He, Yaqian; Xu, Rongting; Prior, Stephen A.; Yang, Di; Yang, Anni; and Chen, Jian, "Satellite-detected ammonia changes in the United States: Natural or anthropogenic impacts" (2021). USDA Wildlife Services - Staff Publications. 2475.

https://digitalcommons.unl.edu/icwdm_usdanwrc/2475

This Article is brought to you for free and open access by the U.S. Department of Agriculture: Animal and Plant Health Inspection Service at DigitalCommons@University of Nebraska - Lincoln. It has been accepted for inclusion in USDA Wildlife Services - Staff Publications by an authorized administrator of DigitalCommons@University of Nebraska - Lincoln. 


\section{Authors}

Yaqian He, Rongting Xu, Stephen A. Prior, Di Yang, Anni Yang, and Jian Chen 


\title{
Satellite-detected ammonia changes in the United States: Natural or anthropogenic impacts
}

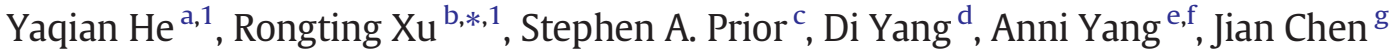 \\ a Department of Geography, University of Central Arkansas, Conway, AR, USA \\ ${ }^{\mathrm{b}}$ Forest Ecosystems and Society, Oregon State University, Corvallis, OR, USA \\ c USDA-ARS National Soil Dynamics Laboratory, Auburn, AL, USA \\ d Wyoming Geographic Information Center, University of Wyoming, Laramie, WY, USA \\ e Department of Fish, Wildlife, and Conservation Biology, Colorado State University, Fort Collins, CO, USA \\ ${ }^{\mathrm{f}}$ National Wildlife Research Center, United States Department of Agriculture, Animal and Plant Health Inspection Service, Fort Collins, CO, USA \\ ${ }^{g}$ Department of Computer Science and Software Engineering, Samuel Ginn College of Engineering, Auburn University, Auburn, AL, USA
}

\section{H I G H L I G H T S}

- Besides the US Midwest, a striking increase in $\mathrm{NH}_{3}$ concentrations was also detected in the Mid-South and Western regions.

- Warmer winters in the West and hot summers in the Mid-South and Midwest highly accounted for increased $\mathrm{NH}_{3}$ emissions there.

- Synthetic $\mathrm{N}$ fertilizer interaction with temperature could stimulate $\mathrm{NH}_{3}$ releases, especially in more vulnerable regions.

\section{A R T I C L E I N F O}

\section{Article history:}

Received 6 March 2021

Received in revised form 6 May 2021

Accepted 17 May 2021

Available online 25 May 2021

Editor: Pingqing Fu

\section{Keywords:}

Ammonia

AIRS

GTWR

Synthetic nitrogen fertilizer

Livestock manure

Climate change
G R A P H I C A L A B S T RACT

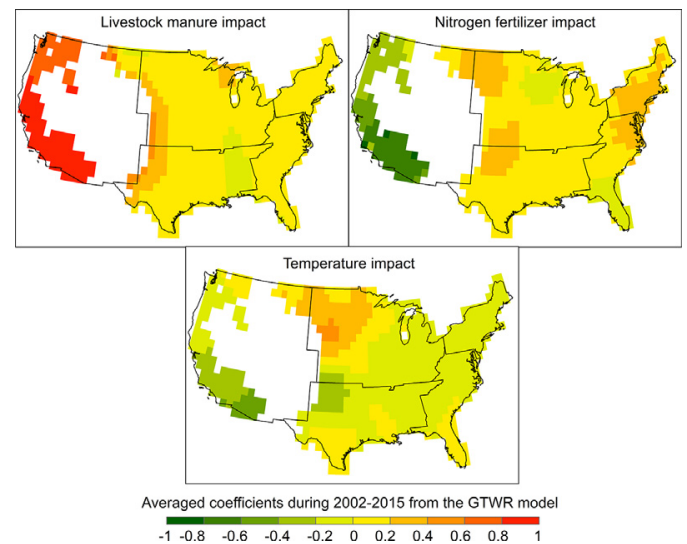

\section{A B S T R A C T}

Ammonia $\left(\mathrm{NH}_{3}\right)$ is the most abundant alkaline component and can react with atmospheric acidic species to form aerosols that can lead to numerous environmental and health issues. Increasing atmospheric $\mathrm{NH}_{3}$ over agricultural regions in the US has been documented. However, spatiotemporal changes of $\mathrm{NH}_{3}$ concentrations over the entire US are still not thoroughly understood, and the factors that drive these changes remain unknown. Herein, we applied the Atmospheric Infrared Sounder (AIRS) monthly $\mathrm{NH}_{3}$ dataset to explore spatiotemporal changes in atmospheric $\mathrm{NH}_{3}$ and the empirical relationships with synthetic $\mathrm{N}$ fertilizer application, livestock manure production, and climate factors across the entire US at both regional and pixel levels from 2002 to 2016 . We found that, in addition to the US Midwest, the Mid-South and Western regions also experienced striking increases in $\mathrm{NH}_{3}$ concentrations. $\mathrm{NH}_{3}$ released from livestock manure during warmer winters contributed to increased annual $\mathrm{NH}_{3}$ concentrations in the Western US. The influence of temperature on temporal evolution of $\mathrm{NH}_{3}$ concentrations was associated with synthetic $\mathrm{N}$ fertilizer use in the Northern Great Plains. With a strong positive impact of temperature on $\mathrm{NH}_{3}$ concentrations in the US Midwest, this region could possibly become an atmospheric $\mathrm{NH}_{3}$ hotspot in the context of future warming. Our study provides an essential scientific basis for US policy makers in developing mitigation strategies for agricultural $\mathrm{NH}_{3}$ emissions under future climate change scenarios.

(c) 2021 Elsevier B.V. All rights reserved.

\footnotetext{
* Corresponding author.

E-mail address: xuro@oregonstate.edu (R.Xu).

1 These authors contributed equally.
} 


\section{Introduction}

Over the last century, the global nitrogen $(\mathrm{N})$ cycle has been heavily perturbed by additions of reactive $\mathrm{N}$ from human activities, including combustion-related nitrogen oxides $\left(\mathrm{NO}_{x}\right)$, industrial ammonia $\left(\mathrm{NH}_{3}\right)$ production through the Haber-Bosch process, and agricultural $\mathrm{N}$ fixation (Fowler et al., 2015). These anthropogenic activities have considerably increased atmospheric $\mathrm{NO}_{x}$ and $\mathrm{NH}_{3}$ (Tian et al., 2020; Xu et al., 2019). Synthetic $N$ fertilizer application and livestock manure management are two dominant atmospheric $\mathrm{NH}_{3}$ sources that account for $\sim 80 \%$ of total $\mathrm{NH}_{3}$ emission in the US (Davidson et al., 2011). Meanwhile, $\mathrm{NH}_{3}$ volatilization can be regulated by changing climate. Recent studies have demonstrated that climate warming may favor $\mathrm{NH}_{3}$ release from multiple surface layers such as soil, stomates, and moisture layers on leaf cuticles (Shen et al., 2020a; Xu et al., 2019). Shen et al. (2020a) projected that climate warming would increase $\mathrm{NH}_{3}$ emissions by $18 \%$ and lead to a considerable drop in crop yield due to a $10 \%$ loss of applied N. This could also induce a $14 \%$ increase in $\mathrm{NH}_{4}^{+}$deposition to sensitive ecosystems across the US over the 2010 to 2100 time span (Shen et al., 2020a). Increased atmospheric $\mathrm{NH}_{3}$ can cause a number of environmental issues. $\mathrm{NH}_{3}$ is the most abundant alkaline component and can neutralize acidic species such as $\mathrm{SO}_{2}$ and $\mathrm{NO}_{x}$ to form atmospheric aerosols (e.g., $\mathrm{PM}_{2.5}$ ) that can reduce visibility and threaten human health and life expectancy (Bauer et al., 2016; Xu et al., 2018). Moreover, dry and wet depositions of $\mathrm{NH}_{4}^{+}$from $\mathrm{NH}_{3}$ emissions may alter soil and water chemistry (e.g., eutrophication) and reduce biological diversity (Clark and Tilman, 2008). Thus, better understanding of atmospheric $\mathrm{NH}_{3}$ magnitudes, trends, and spatial patterns is essential to avoid negative effects on human health and ecosystem function in the US.

Numerous studies have examined changes in spatiotemporal patterns of atmospheric $\mathrm{NH}_{3}$ concentration (Li et al., 2017; Nair et al., 2019; Van Damme et al., 2020; Van Damme et al., 2018; Warner et al., 2017), agricultural $\mathrm{NH}_{3}$ emissions (Cao et al., 2020; Shen et al., 2020a; $\mathrm{Xu}$ et al., 2018; Xu et al., 2019), and wet $\mathrm{NH}_{4}^{+}$deposition (Du, 2016; Du et al., 2014) over the US using a variety of bottom-up and topdown approaches. For instance, Nair et al. (2019) used a global 3-D chemical transport model (GEOS-Chem) to simulate $\mathrm{NH}_{3}$ concentration based on surface observations from 90 National Atmospheric Deposition Program Ammonia Monitoring Network (AMoN) sites. They found that $\mathrm{NH}_{3}$ concentration was highly emission dependent and dominated by agricultural activities, with high $\mathrm{NH}_{3}$ emissions in the Central US and Western US due to $\mathrm{N}$ fertilizer applications and livestock grazing, respectively. A similar conclusion was reached by Van Damme et al. (2018), who found that intensive animal farming can contribute to numerous hotspots of $\mathrm{NH}_{3}$ emissions across the Western US (e.g., Eckley-Yuma, Colorado; Bakersfield and Tulare, California; and Milford, Utah); this work was based on a high-resolution map of atmospheric ammonia obtained from daily Infrared Atmospheric Sounding Interferometer (IASI) satellite observations over the past decade. In contrast, a recent study on synthetic $\mathrm{N}$ fertilizer application identified that increased $\mathrm{NH}_{3}$ emission hot spots have shifted from the Central US to the Northern Great Plains since 1960 (Cao et al., 2020). Spatiotemporal patterns of $\mathrm{NH}_{4}^{+}$deposition have also been examined. By analyzing 151 site-level annual wet deposition data from the National Atmospheric Deposition Program (NADP), Du et al. (2014) noted that wet $\mathrm{NH}_{4}^{+}$deposition significantly increased over the 1985-2012 period in the Midwest, South, and Western regions of the US. The increased $\mathrm{NH}_{4}^{+}$deposition in the West and Midwest was associated with large animal breeding (e.g., hogs and cattle) and $\mathrm{N}$ fertilizer application, while the increase in the Southeast was associated with smaller livestock (e.g., chickens) (Stephen and Aneja, 2008). However, no above-mentioned study has simultaneously considered natural and anthropogenic impacts on decadal spatiotemporal changes in US $\mathrm{NH}_{3}$ concentrations. Moreover, geographical and temporal weighted regression (GTWR), a unique statistical technique, is capable of accounting for local effects in both space and time (Fotheringham et al., 2015) and has been widely applied in research fields of economics
(Qu et al., 2020), transportation (Shen et al., 2020b), infectious disease (Hong et al., 2021), biology (Cullen and Guida, 2021), etc. Our study is a first attempt to examine spatiotemporal influence of climate variability and anthropogenic nitrogen additions on $\mathrm{NH}_{3}$ concentration dynamics using a GTWR model.

In recent years, satellite-based data have become a promising way to monitor global atmospheric $\mathrm{NH}_{3}$ due to the relatively high temporal and spatial coverage (Van Damme et al., 2020; Van Damme et al., 2018; Warner et al., 2017). Van Damme et al. (2020) analyzed an 11-year $\mathrm{NH}_{3}$ dataset (2008 to 2018) obtained from daily IASI satellite observations and found a large increase in atmospheric $\mathrm{NH}_{3}$ for the US that was highly concentrated in the Midwest. Using a dataset from the Atmospheric Infrared Sounder (AIRS) on the Aqua satellite, Warner et al. (2016) evaluated a comprehensive monitoring of 13-year global tropospheric $\mathrm{NH}_{3}$ distribution. Spatiotemporal patterns from satellite data suggested that the main source of atmospheric $\mathrm{NH}_{3}$ was from farming and animal husbandry activities involving reactive $\mathrm{N}$ derived from synthetic $\mathrm{N}$ fertilizer use (Warner et al., 2017). Nevertheless, there are several limitations of previous studies that applied satellite data. First, most studies primarily relied on a national-level, one-year synthetic $\mathrm{N}$ fertilizer application map and ignored information on livestock manure management across the US. Second, how changes in spatiotemporal patterns of synthetic $\mathrm{N}$ fertilizer application and livestock manure management affect atmospheric $\mathrm{NH}_{3}$ concentration across the US is still an open question. Third, most previous studies used a global linear regression model to explore relationships between $\mathrm{NH}_{3}$ and driving factors, where the regression coefficient for each forcing factor remained constant across space and time (Chu et al., 2015; Hou et al., 2015). However, spatiotemporal non-stationarity exists in $\mathrm{NH}_{3}$ and associated forcing variables. In addition, although hot and dry summers were found to be associated with high $\mathrm{NH}_{3}$ concentrations in the Midwest (Warner et al., 2017), such relationships have not been examined in other US regions. Furthermore, Warner et al. (2017) may have overlooked potential underlying mechanisms that favored increases in atmospheric $\mathrm{NH}_{3}$ across the US. Finally, climate change (e.g., increasing temperature) could exacerbate $\mathrm{NH}_{3}$ emissions from highly fertilized croplands (Xu et al., 2019; Shen et al., 2020a, 2020b; Ma et al., 2021). Possible interactions between $\mathrm{N}$ additions and climate change have been largely ignored in previous work (Warner et al., 2017).

To address these limitations, the current study applied a satellitebased, 14-year monthly $\mathrm{NH}_{3}$ dataset to explore change in spatiotemporal $\mathrm{NH}_{3}$ patterns and the empirical relationships with synthetic $\mathrm{N}$ fertilizer application, livestock manure production, and climate factors across the US at both regional and pixel levels (Fig. 1). To reveal spatiotemporal variations of these relationships, this study used a GTWR model in an attempt to answer the following questions: 1) What was the spatiotemporal change pattern of $\mathrm{NH}_{3}$ from 2002 to 2016? 2) What were the empirical associations of $\mathrm{NH}_{3}$ with anthropogenic and climatic variables? 3) How did empirical associations evolve across space and time? and 4) What were potential physical mechanisms underlying changing $\mathrm{NH}_{3}$ patterns?

The rest of the paper is organized as follows: In Section 2, we describe the data used in this study, including satellite-based $\mathrm{NH}_{3}$ measurements, climate (i.e., temperature and precipitation), synthetic $\mathrm{N}$ fertilizer, and livestock manure. We also explain the statistical methods of trend analysis, correlation analysis, and GTWR. Section 3 presents the results of spatiotemporal associations between $\mathrm{NH}_{3}$ concentration and three impact factors; limitations and future directions of study are also discussed. Section 4 is the conclusion.

\section{Materials and methods}

\subsection{Data}

Five spatially and temporally explicit datasets for the entire US were used: 1) monthly satellite-based $\mathrm{NH}_{3}$ measurements, 2) monthly 
Data layers

Statistical analyses

Trend analysis

1. Regional Kendall Test (RKT)

Correlation analysis

2. Spearman's partial correlation

Spatiotemporal analysis

3. Geographical and Temporal

Weighted Regression (GTWR)
Results

Tables

Tables $1 \&$ S1, 2 \& S2

Tables

Tables 3 \& S3

Figures

Fertilizer impact - Figure 4

Manure impact - Figure 5

Temperature impact-Figure 6

Fig. 1. Flowchart of the methodology for investigating spatiotemporal changes in $\mathrm{NH}_{3}$ concentrations.

temperature, 3) monthly precipitation, 4) annual synthetic $\mathrm{N}$ fertilizer application, and 5) annual livestock manure production. Atmospheric $\mathrm{NH}_{3}$ concentrations (September 2002 to August 2016) were obtained from AIRS. Validating against in situ data, vertical profiles of AIRS $\mathrm{NH}_{3}$ were found to have small biases (within $~ 5-15 \%$ of retrieved profiles) in central California, despite possible biases associated with spatial resolution differences between the two instruments (Warner et al., 2016). The AIRS $\mathrm{NH}_{3}$ products provide $\mathrm{NH}_{3}$ volume mixing ratios (VMRs) at multiple levels from $500 \mathrm{hPa}$ to the surface at a spatial resolution of $1^{\circ} \times 1^{\circ}$. More detailed information regarding the AIRS $\mathrm{NH}_{3}$ retrieval method can be found in Warner et al. (2016, 2017). In this study, we selected $\mathrm{NH}_{3}$ VMRs at $918 \mathrm{hPa}$ (i.e., peak sensitivity) according to Warner et al. (2017). Surface temperature and precipitation from 2002 to 2016 were obtained from Daily Surface Weather Data version 3 (Daymet; Thornton et al. (2016)) with a spatial resolution of $1 \mathrm{~km}$. Daymet generated daily weather and climatology variables through interpolating and extrapolating ground-based observations using statistical modeling techniques (Thornton et al., 2016). A spatially explicit data set of synthetic $\mathrm{N}$ fertilizer use during 2002-2015 was obtained from Cao et al. (2018) at a spatial resolution of $5 \mathrm{~km} \times 5 \mathrm{~km}$. Spatially explicit livestock manure production between 2002 and 2016 was obtained from Bian et al. (2021) at a spatial resolution of $30 \mathrm{~s} \times 30 \mathrm{~s}$. Climatic, N fertilizer, and manure datasets were aggregated into $1^{\circ} \times 1^{\circ}$ grids to be consistent with $\mathrm{NH}_{3}$ data.

\subsection{Statistical analysis}

We applied the non-parametric Regional Kendall Test (RKT) to examine overall trends of atmospheric $\mathrm{NH}_{3}$ concentrations and four driving factors (i.e., temperature, precipitation, synthetic $\mathrm{N}$ fertilizer, and livestock manure production) for five regions and the entire US. The five regions were the West, Midwest, Mid-South, Southeast, and Northeast (Fig. 2a). To explore associations of $\mathrm{NH}_{3}$ with mean monthly temperature (MMT) and precipitation (MMP), we performed a nonparametric Spearman's partial correlation. Trend and correlation analyses were carried out in R software for Windows (version 4.0.3, www.r-project.org/). The RKT was performed using the 'RKT package' with the estimated Theil-Sens slope (Marchetto et al., 2013). The Spearman's partial correlation was performed using the 'ppcor package' (Kim, 2015). a

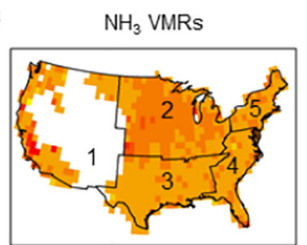

ppbv

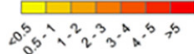

f

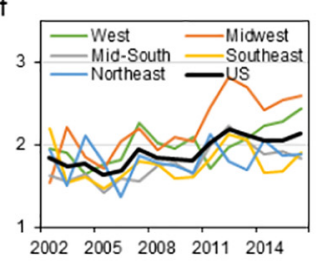

b

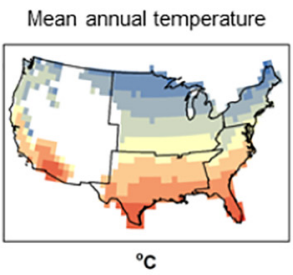

${ }^{\circ} \mathrm{C}$

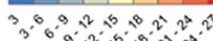

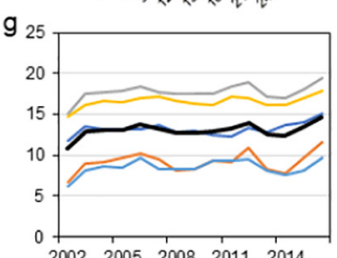

C Mean annual precipitation

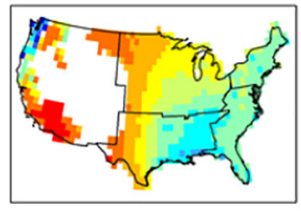

$\mathrm{mm}$

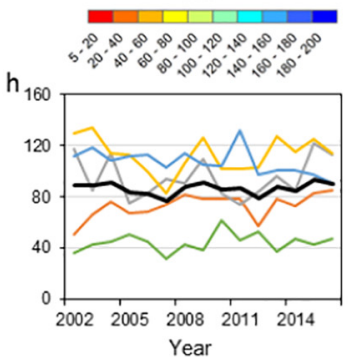

d

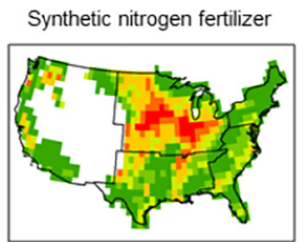

$\operatorname{Tg~N~} \mathrm{yr}^{-1}$

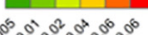

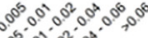
$0.0,0.0 .0 .000$

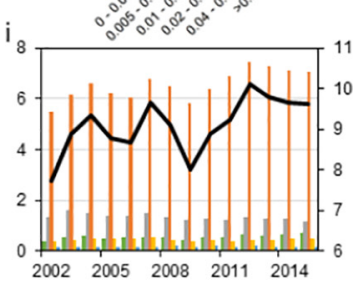

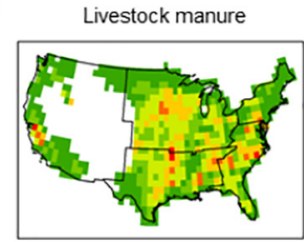

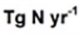

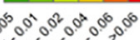

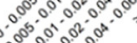

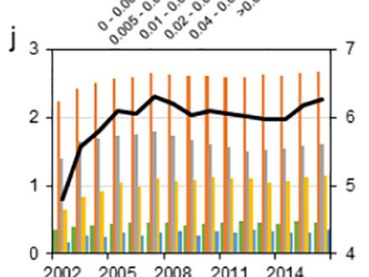

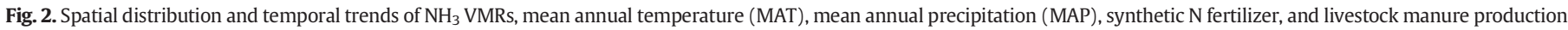

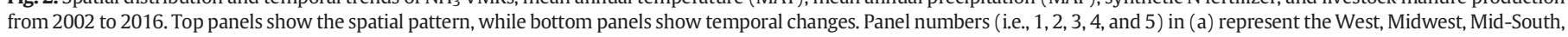
Southeast, and Northeast regions of the US, respectively. 


\subsection{The GTWR model}

To reveal magnitudes of $\mathrm{N}$ fertilizer, livestock manure, and climatic impacts on $\mathrm{NH}_{3}$ and how such magnitudes change across space and time, this study applied GTWR at an annual scale for each grid cell in the US. As an extension of a traditional regression model, the GTWR model can simultaneously consider both spatial and temporal heteroscedasticity and thus provide spatiotemporal estimations (Chu et al., 2015; Huang et al., 2010; Wu et al., 2019). The GTWR model can be described as:

$Y_{i}=\beta_{0}\left(u_{i}, v_{i}, t_{i}\right)+\sum_{k} \beta_{k}\left(u_{i}, v_{i}, t_{i}\right) X_{i k}+\varepsilon_{i}$

where $Y_{i}$ is the dependent variable of the $i$ th sample (i.e., $\mathrm{NH}_{3}$ in this study), $X_{i k}$ are the independent variables of the $i$ th sample (i.e., $\mathrm{N}$ fertilizer, livestock manure, climate variables in this study), $u_{i}, v_{i}$, and $t_{i}$ are the space-time coordinates of the $i$ th sample, and $\beta_{k}\left(u_{i}, v_{i}, t_{i}\right)$ is the estimated coefficient of the $k$ th independent variable for the $i$ th sample. The weighted least squares (WLS) approach was adopted to calibrate GTWR (Huang et al., 2010). The matrix expression for the estimated coefficient of the ith sample can be expressed as:

$\widehat{\beta}_{k}\left(u_{i}, v_{i}, t_{i}\right)=\left[X^{\mathrm{T}} W\left(u_{i}, v_{i}, t_{i}\right) X\right]^{-1} X^{\mathrm{T}} W\left(u_{i}, v_{i}, t_{i}\right) Y$

where $W\left(u_{i}, v_{i}, t_{i}\right)$ is a spatiotemporal weight matrix that can be measured using a variety of distance-decay functions, such Gaussian, bi-square, and exponential functions. In this study, we used a Gaussian kernel function (Huang et al., 2010):

$W_{i j}^{S T}=\exp \left[\left(\frac{d_{i j}^{s t}}{h^{s t}}\right)^{2}\right]$

where $d_{i j}^{s t}$ is the spatiotemporal distance between samples $i$ and $j$, and $\left(d_{i j}^{s t}\right)^{2}=\lambda\left[\left(u_{i}-u_{j}\right)^{2}-\left(v_{i}-v_{j}\right)^{2}\right]+\mu\left(t_{i}-t_{j}\right)^{2}$. Here, $\lambda$ and $\mu$ are scale factors used to balance difference effects employed to measure spatial and temporal distances in their respective metric systems, and $h^{\text {st }}$ is the spatiotemporal bandwidth and $h^{s t}=h^{s}+\varphi * h^{t}$. The optimal spatial bandwidth $h^{s}$ and temporal bandwidth $h^{t}$ can be obtained using a corrected version of the Akaike information criterion (AICc) (Hurvich et al., 1998).

To make direct comparisons among different covariates, we standardized dependent and independent variables using the 'scale' function in R. We also compared the R-square $\left(R^{2}\right)$ from GTWR with that from the global regression model (i.e., ordinary least squares (OLS)) to assess GTWR performance. We selected $\mathrm{NH}_{3}$ as the dependent variable and $\mathrm{N}$ fertilizer, livestock manure, and temperature as independent variables for both GTWR and OLS models. The selection was described in Section 3.3. The GTWR and OLS simulations were conducted using the GTWR AddIn in ESRI ArcMap 10.8 developed by Huang et al. (2010).

\section{Results and discussion}

\subsection{Trends in $\mathrm{NH}_{3}$ concentrations and driving factors for five US regions}

Across the US, atmospheric $\mathrm{NH}_{3}$ concentrations significantly increased by 0.030 ppbv yr $^{-1}$ between 2002 and 2016 (Table 1). The US Midwest has been identified as a global hotspot for $\mathrm{NH}_{3}$ emissions based on satellite observations (Griffis et al., 2019; Shephard et al., 2011; Van Damme et al., 2020). We found that the Midwest had the highest $\mathrm{NH}_{3}$ concentrations among all five regions (Fig. 2f) with the largest rate increase of $0.074 \mathrm{ppbv} \mathrm{yr}^{-1}$ ( $p$-value $<0.01$ ). This was con-

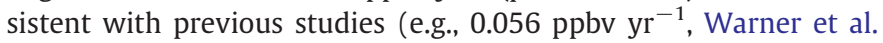
(2017)). In addition, our analysis of ARIS $\mathrm{NH}_{3}$ trends in the Midwest (3.8\%, a compound annual growth rate) was in line with trends obtained from the IASI- $\mathrm{NH}_{3}$ dataset during 2008-2018 (3.42\% $\pm 0.59 \%$, Van Damme et al. (2020)). In contrast, the Southeast and Northeast
Table 1

Regional Kendall test of regional trends for atmospheric $\mathrm{NH}_{3}$ concentrations in the US from 2002 to 2016.

\begin{tabular}{llllll}
\hline Region & \multicolumn{2}{l}{ Monthly } & & \multicolumn{2}{l}{ Annual } \\
\cline { 2 - 3 } \cline { 5 - 6 } & Slope & $\mathrm{p}$ & & Slope & $\mathrm{p}$ \\
\hline West & 0.032 & $<0.001$ & & 0.038 & $<0.01$ \\
Midwest & 0.043 & $<0.001$ & & 0.074 & $<0.01$ \\
Mid-South & 0.033 & $<0.001$ & & 0.030 & $<0.01$ \\
Southeast & 0.013 & $<0.050$ & & 0.015 & 0.11 \\
Northeast & 0.026 & $<0.050$ & & 0.010 & 0.55 \\
The United States & 0.028 & $<0.001$ & & 0.030 & $<0.05$ \\
\hline
\end{tabular}

showed slight increases in annual $\mathrm{NH}_{3}$ concentrations that were not statistically significant ( $p$-value $=0.11$ and 0.55 , respectively). The Mid-South and West regions showed a medium increase in $\mathrm{NH}_{3}$

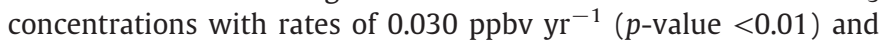

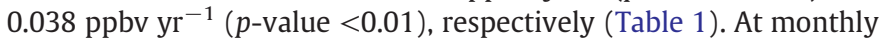
scales, $\mathrm{NH}_{3}$ concentration trends were broadly consistent with those of annual scales (Table 1); however, the significance of $\mathrm{NH}_{3}$ concentrations in the Southeast and Northeast regions increased (Table 1). This was likely associated with the growing frequency of extreme high $\mathrm{NH}_{3}$ concentrations in later years due to climate variability. For example, we found that the highest value of 5.2 ppbv in April 2011 in the Northeast was smoothed out in the annual mean value (Figs. $2 \mathrm{f} \& 3 e$ ), thus there was no observable increase in annual $\mathrm{NH}_{3}$ concentrations.

Mean annual temperatures (MAT) during the study period were much higher across southern regions (i.e., Mid-South and Southeast) compared to northern regions (i.e., Midwest and Northeast) (Fig. 2b), which was expected due to latitudinal effects of solar radiation. In terms of mean annual precipitation (MAP), the Northeast and Southeast were higher than remaining regions, especially the western US (Fig. 2c). Rainfall patterns were mainly due to topography of the West and moisture from the Gulf of Mexico for the East (Hu et al., 1998; Karl and Knight, 1998). Overall, there were no statistically significant trends in mean annual and monthly temperature and precipitation across the five regions from 2002 to 2016 (Tables S1, S2). However, both temperature and precipitation exhibited large intra- and inter-annual variability for this period (Figs. 2g, h \& 3).

Hotspots of synthetic $\mathrm{N}$ fertilizer use were concentrated in the Midwestern US, the Mississippi Valley, and some regions of the Western US (e.g., California) (Fig. 2d). In contrast, hotspots of livestock manure production were spread across all five regions with a much higher amount detected in the states of California, North Carolina, Iowa, and Arkansas (Fig. 2e). The total amount of US fertilizer use increased at a rate of $0.092 \mathrm{Tg} \mathrm{N} \mathrm{yr}^{-1}$ ( $p$-value $<0.05$ ) from 2002 to 2015 (Table 2), however, with annual fluctuations (Fig. 2i). For example, the substantial drop in fertilizer consumption between 2008 and 2009 was largely associated with the high price of fertilizer caused by the 2008 financial crisis (USDA-ERS, 2013). The Midwest, accounting for $~ 80 \%$ of the total national fertilizer consumption, dominated the increase across the US during the study period (Fig. $2 \mathrm{i}$ ). The national total manure production depicted a rapid increase from 2002 to 2008 and then roughly remained constant thereafter (Fig. 2j). At the regional scale, with the exception of the Mid-South, the remaining four regions showed statistically significant increases in livestock manure production for the period of 2002-2016 (Table 2). The Midwest was the largest contributor to national total manure production, followed by the Mid-South and Southeast (Fig. 2j).

\subsection{Monthly $\mathrm{NH}_{3}$ concentration response to climate factors}

Spearman's partial correlation analyses revealed that monthly atmospheric $\mathrm{NH}_{3}$ concentrations were positively correlated with monthly surface temperature in the five US regions (Table 3). The highest correlation coefficient was noted in the Mid-South ( $r$-value $=0.651$ ), followed by the Midwest $(r$-value $=0.272$ ) and West ( $r$-value $=$ 0.262 ) regions. In contrast, only the Mid-South showed a significantly 

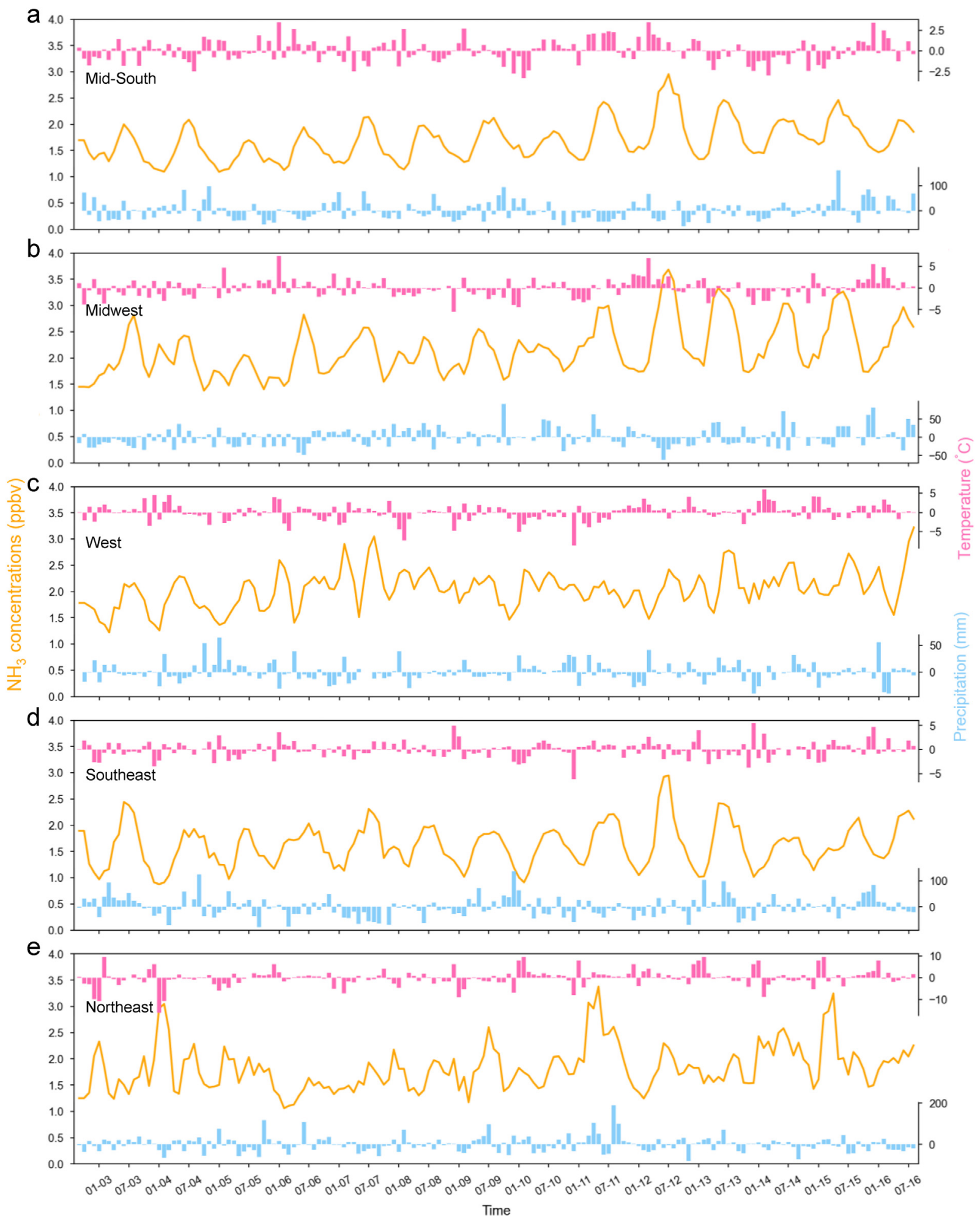

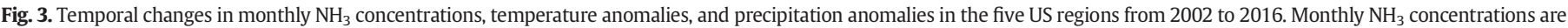
shown as 5-month moving averages. Monthly temperature and precipitation anomalies were calculated by subtracting the 14 -year average of each month.

positive correlation between precipitation and atmospheric $\mathrm{NH}_{3}$ concentrations (Table 3).

Consistent with high-resolution maps of IASI $\mathrm{NH}_{3}$ seasonality and AMoN (Wang et al., 2021), a single summer peak was observed from AIRS $\mathrm{NH}_{3}$ in the Mid-South. There were higher peak temperatures in summers of 2011 and 2012 in the Mid-South, and elevated $\mathrm{NH}_{3}$ concentrations were also detected during this period (Fig. 3a). We also saw a peak $\mathrm{NH}_{3}$ concentration in the summer of 2015 that coincided with extremely heavy rainfall (Fig. 3a). This could be due to rice production since rice is the third largest among cereals (after corn and wheat) in the US and $80 \%$ of rice farms are located in the Mid-South (USDA, NASS). Ma et al. (2021) pointed out that rice cultivation served as the leading background source of $\mathrm{NH}_{3}$ emissions due to high temperatures and waterlogging. In our study, we found a significantly positive correlation between MMP and atmospheric $\mathrm{NH}_{3}$ concentrations in the MidSouth (Table $3, p$-value $<0.01$ ). Rice cultivation requires a substantial 
Table 2

Regional Kendall test of regional trends for synthetic $\mathrm{N}$ fertilizer and livestock manure production in the US from 2002 to 2016.

\begin{tabular}{lccccc}
\hline Region & \multicolumn{2}{l}{ Fertilizer } & & \multicolumn{2}{l}{ Manure } \\
\cline { 2 - 3 } \cline { 5 - 6 } & Slope & $\mathrm{p}$ & & Slope & $\mathrm{p}$ \\
\hline West & 0.015 & $<0.05$ & & 0.005 & $<0.05$ \\
Midwest & 0.092 & $<0.05$ & & 0.014 & $<0.05$ \\
Mid-South & -0.022 & $<0.05$ & & -0.011 & 0.276 \\
Southeast & 0.002 & $<0.05$ & & 0.006 & $<0.05$ \\
Northeast & 0.004 & 0.346 & & 0.018 & $<0.001$ \\
The United States & 0.092 & $<0.05$ & & 0.026 & 0.198 \\
\hline
\end{tabular}

amount of water either from irrigation or from rainfall, and sufficient water supply favors $\mathrm{NH}_{3}$ releases since urea can react with water and the urease enzyme to produce ammonium carbonate (unstable compound that quickly decomposes to release $\mathrm{NH}_{3}$ gas).

The positive correlation between surface temperature and $\mathrm{NH}_{3}$ found in the Midwest was in conformity with Warner et al. (2017) who reported that high average surface temperatures in the US Midwest could facilitate $\mathrm{NH}_{3}$ emissions. The positive feedback between $\mathrm{NH}_{3}$ concentrations and temperature was also supported by Hu et al. (2021), who found that $\mathrm{NH}_{3}$ emissions peaked from May to July in 2017 in the US Corn Belt by combining tall tower, ground-based measurements, and modeling. In addition, a $2.5^{\circ} \mathrm{C}-3.6^{\circ} \mathrm{C}$ higher air temperature led to abnormally higher $\mathrm{NH}_{3}$ concentrations in May 2018 compared to other months in the study region. We observed that high $\mathrm{NH}_{3}$ concentrations in 2012 coincided with high summer temperature and low rainfall (Fig. 3b), which was supported by Warner et al. (2017) where hot and dry summers were conducive to high $\mathrm{NH}_{3}$ concentrations. However, this pattern did not persist across years. For example, our results for 2011 showed a similarly high $\mathrm{NH}_{3}$ concentration in summer with heavy rainfall (Fig. 3b). Table 3 shows a weak relationship between $\mathrm{NH}_{3}$ concentrations and MMP in the Midwest, which may indicate that other factors such as soil moisture, $\mathrm{pH}$, and soil inorganic $\mathrm{N}$ content could also affect monthly variations in $\mathrm{NH}_{3}$ concentration.

The West region received minimal annual rainfall and was the driest area in the US (Figs. 2c, h). We found a significantly positive correlation between surface temperature and $\mathrm{NH}_{3}$ in this region (Table 3 ). Timeseries temperature data revealed that winters in the West became warmer since 2011 despite summer temperatures being similar during 2002-2016 (Fig. 3c). Increased $\mathrm{NH}_{3}$ released from livestock manure during warmer winters possibly contributed to increased annual $\mathrm{NH}_{3}$ concentrations.

In the Northeast and Southeast, positive correlations between surface temperature and $\mathrm{NH}_{3}$ were weak. For the Northeast, many missing monthly $\mathrm{NH}_{3}$ concentration values may have affected correlation analysis results. For the Southeast, there were peak $\mathrm{NH}_{3}$ concentrations in summers due to high temperatures (Fig. 3d). Annual rainfall in the Northeast and Southeast were much higher than in remaining US regions, and heavy rainfall usually occurred in summer months. Frequent rainfall events could have washed livestock manure into riverine ecosystems, leading to low $\mathrm{NH}_{3}$ emissions in both regions.

\section{Table 3}

Summary of Spearman's partial correlation test for monthly mean temperature and precipitation with $\mathrm{NH}_{3}$ concentration.

\begin{tabular}{lll}
\hline \multirow{2}{*}{ Region } & \multicolumn{2}{l}{ Correlation coefficient } \\
\cline { 2 - 3 } & $\mathrm{NH}_{3} \sim \mathrm{MMT}$ & $\mathrm{NH}_{3} \sim \mathrm{MMP}$ \\
\hline West & $0.262^{* * * *}$ & 0.039 \\
Midwest & $0.270^{* * * *}$ & 0.109 \\
Mid-South & $0.651^{* * *}$ & $0.213^{* *}$ \\
Southeast & $0.210^{* * *}$ & 0.001 \\
Northeast & $0.201^{* *}$ & 0.017 \\
The United States & $0.510^{* * *}$ & $0.156^{* *}$ \\
\hline
\end{tabular}

** Indicates statistical significance at 0.01 level.

*** Indicates statistical significance at 0.001 level.
It is worth noting that large discrepancies remain in monthly $\mathrm{NH}_{3}$ concentrations observed from different satellites. High-resolution $\mathrm{NH}_{3}$ column maps from IASI found that springs exhibited the maximum level of $\mathrm{NH}_{3}$ concentrations, which was consistent with fertilizer application timing in the Midwest (Wang et al., 2021), while summer peaks detected by AIRS in our study were consistent with measurements from AMoN. Unlike the narrow summer peaks of IASI $\mathrm{NH}_{3}$ in the western US (Wang et al., 2021), AIRS $\mathrm{NH}_{3}$ showed bimodal peaks (one in both summer and winter) or relatively insignificant seasonal variability in some years (Fig. 3c). This large discrepancy is partially attributed to missing data and much coarser spatial resolution of the AIRS $\mathrm{NH}_{3}$ product. Similar to the western US, AIRS $\mathrm{NH}_{3}$ did not show obvious single peaks in the Northeast and Southeast for most years (Fig. 3e). However, AIRS $\mathrm{NH}_{3}$ cannot be directly compared with IASI and AMoN due to large inconsistencies in geographic coverage of areas in both regions (Wang et al., 2021).

\subsection{Impacts of anthropogenic and climatic variables on $\mathrm{NH}_{3}$ concentrations}

We ran the GTWR model at the annual scale to examine magnitudes of anthropogenic and climatic influences on annual $\mathrm{NH}_{3}$ concentrations and how such magnitudes change spatiotemporally from 2002 to 2015. In addition, precipitation was excluded in the GTWR model since there were no significant correlations of $\mathrm{NH}_{3}$ concentrations with precipitation across most regions of the US (Section 3.2, Table 3). The following analyses only focused on three driving factors (i.e., $\mathrm{N}$ fertilizer, livestock manure, and temperature).

Figs. 4-6 present the spatiotemporal coefficients computed by the GTWR model for individual driving factors for each grid cell across the US. Our results indicated that the GTWR model reasonably captured the effects of the three driving factors on annual $\mathrm{NH}_{3}$ concentrations; the overall $\mathrm{R}^{2}(\sim 0.205)$ was much higher compared to the OLS regres$\operatorname{sion}\left(\mathrm{R}^{2}=\sim 0.061\right)$. From a regional perspective, the Midwest experienced the most intensive agricultural activities since it received $\sim 80 \%$ of total $\mathrm{N}$ fertilizer and accounted for about half of total US manure production (Fig. 2i, j) (Bian et al., 2021; Cao et al., 2018). Thus, a substantial amount of reactive $\mathrm{N}$ was available for release as $\mathrm{NH}_{3}$ gas in this region. We found that livestock manure had a consistent positive impact on $\mathrm{NH}_{3}$ concentrations spatiotemporally with coefficients ranging from 0 to 0.4 (Fig. 4). However, this effect slightly decreased along with declining stable manure production after 2008 (Fig. 2j). A consistent higher effect of manure was detected in the western part of the Midwest (i.e., Kansas), which had higher temperatures and less precipitation. Nitrogen fertilizer application was another reason for higher $\mathrm{NH}_{3}$ concentrations in the Midwest and its effects continued to enlarge during 2002-2015 with coefficients ranging from -0.2 to 0.6 (Fig. 5). We observed a continuous rise in the effect of $\mathrm{N}$ fertilizer in northern parts of the Midwest (i.e., Northern Great Plains) that was largely associated with increased fertilizer consumption for spring wheat and corn production (Cao et al., 2020).

Our results also revealed that the influence of temperature on temporal evolution of $\mathrm{NH}_{3}$ concentrations was associated with synthetic $\mathrm{N}$ fertilizer use in the Northern Great Plains. Temperature had a positive effect on $\mathrm{NH}_{3}$ concentrations with coefficients as high as 0.8 in the northwestern Midwest, while this effect was weak and ranged from -0.4 to 0 in the eastern Midwest (Fig. 6). This contrasting effect of temperature was highly associated with opposing fertilizer usage (decrease in the eastern Midwest and a rapid increase in the northwest). Our study notably provided evidence that synthetic $\mathrm{N}$ fertilizer interaction with temperature could stimulate $\mathrm{NH}_{3}$ release (especially in more vulnerable regions like the Northern Great Plains), which was neglected in previous studies (Cao et al., 2018; Li et al., 2017; Nair et al., 2019; Warner et al., 2017; Yu et al., 2018). A recent study also observed an increase over some source regions in the US Midwest in summers due to increased temperatures and certain farm practices that promoted greater $\mathrm{NH}_{3}$ volatilization (Shephard et al., 2020). Additionally, the Coupled Model Intercomparison Project Phase 6 (CMIP6) ensemble 

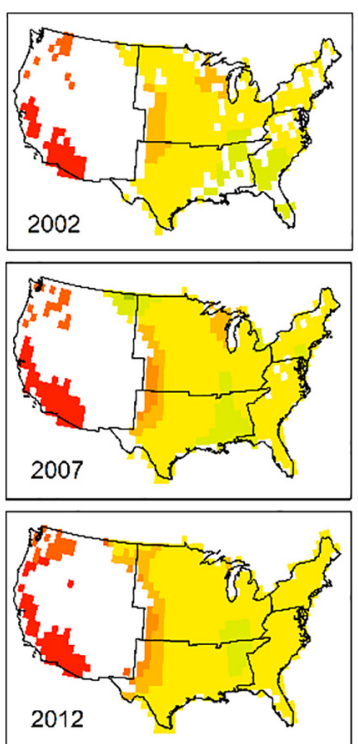
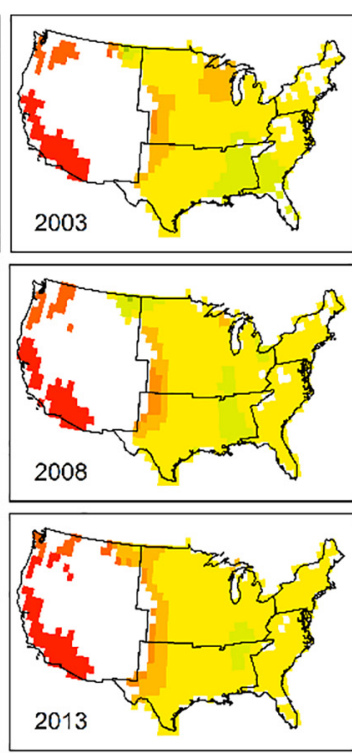

Coefficient

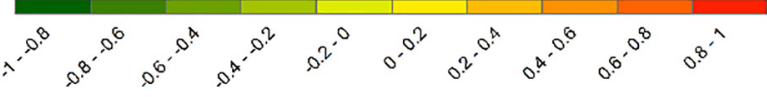
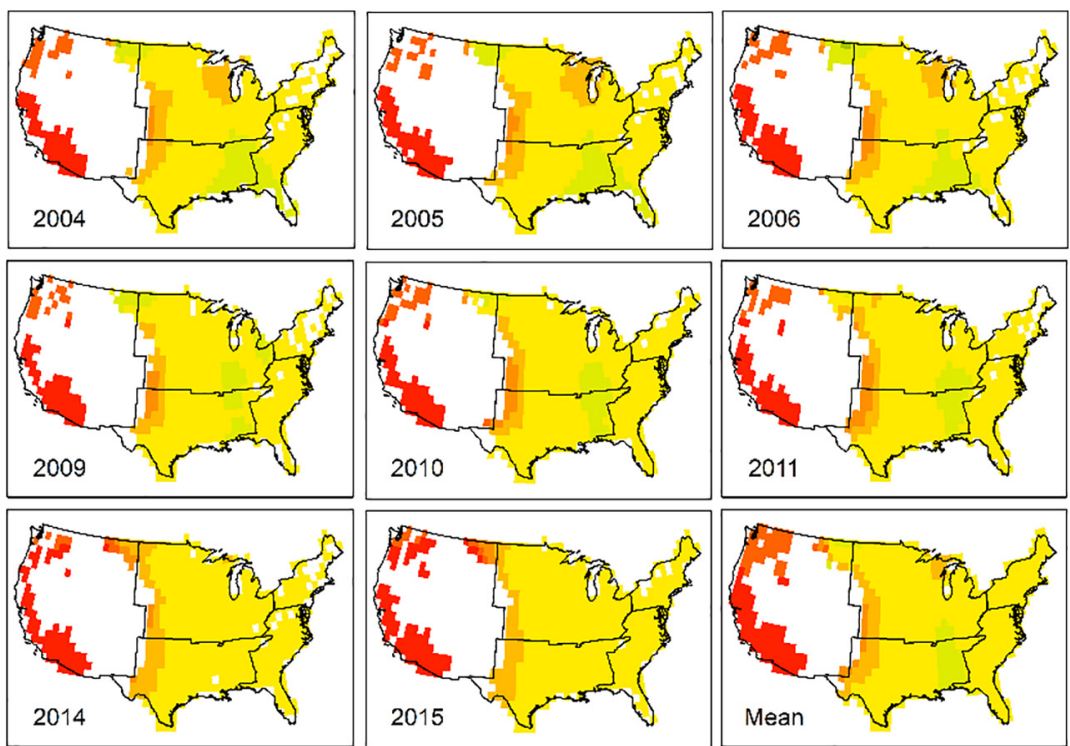

Fig. 4. Spatiotemporal impacts of livestock manure on $\mathrm{NH}_{3}$ concentration for each grid cell during 2002-2015. The last panel is the mean of climatological coefficients.

showed a significant increase in MAT across the US with more pronounced rises in the northern half during 2021-2099 under all three Shared Socioeconomic Pathways (SSPs) (Almazroui et al., 2021). Thus, global warming interactions with substantial $\mathrm{N}$ additions could lead to higher $\mathrm{NH}_{3}$ concentrations and decreased air quality in the US Midwest for the remainder of the century. This is confirmed by a recent study by Shen et al. (2020a) who predicted substantial increases in future $\mathrm{NH}_{3}$ emissions for the Corn Belt and Northern Great Plains (i.e., Midwest in our study) by 2100 in the RCP8.5 climate scenario (i.e., the highest projected emission scenario). Moreover, Hu et al. (2020) found that peak $\mathrm{NH}_{3}$ emissions from the US Corn Belt in November 2017 were associated with above-normal air temperature. Their results imply that future warmer fall temperatures could stimulate agricultural $\mathrm{NH}_{3}$ emissions in the midwestern US due to dense livestock operations and high synthetic nitrogen fertilizer usage.

Followed by the Midwest, the Mid-South also experienced intensive agricultural activities that introduced a considerable amount of reactive $\mathrm{N}$ available for loss in the form of $\mathrm{NH}_{3}$ (Fig. 2i, j). Livestock manure showed persistent positive impacts on $\mathrm{NH}_{3}$ concentrations across time and space in the Mid-South (coefficients ranging from 0 to 0.2 ), except for some eastern parts of this region (Fig. 4). Patterns and magnitudes were similar to the Midwest. In addition, there was a spatiotemporalconsistent pattern of positive effects of $\mathrm{N}$ fertilizer on $\mathrm{NH}_{3}$ concentrations in the Mid-South with coefficients ranging from 0 to 0.6 (Fig. 5). The
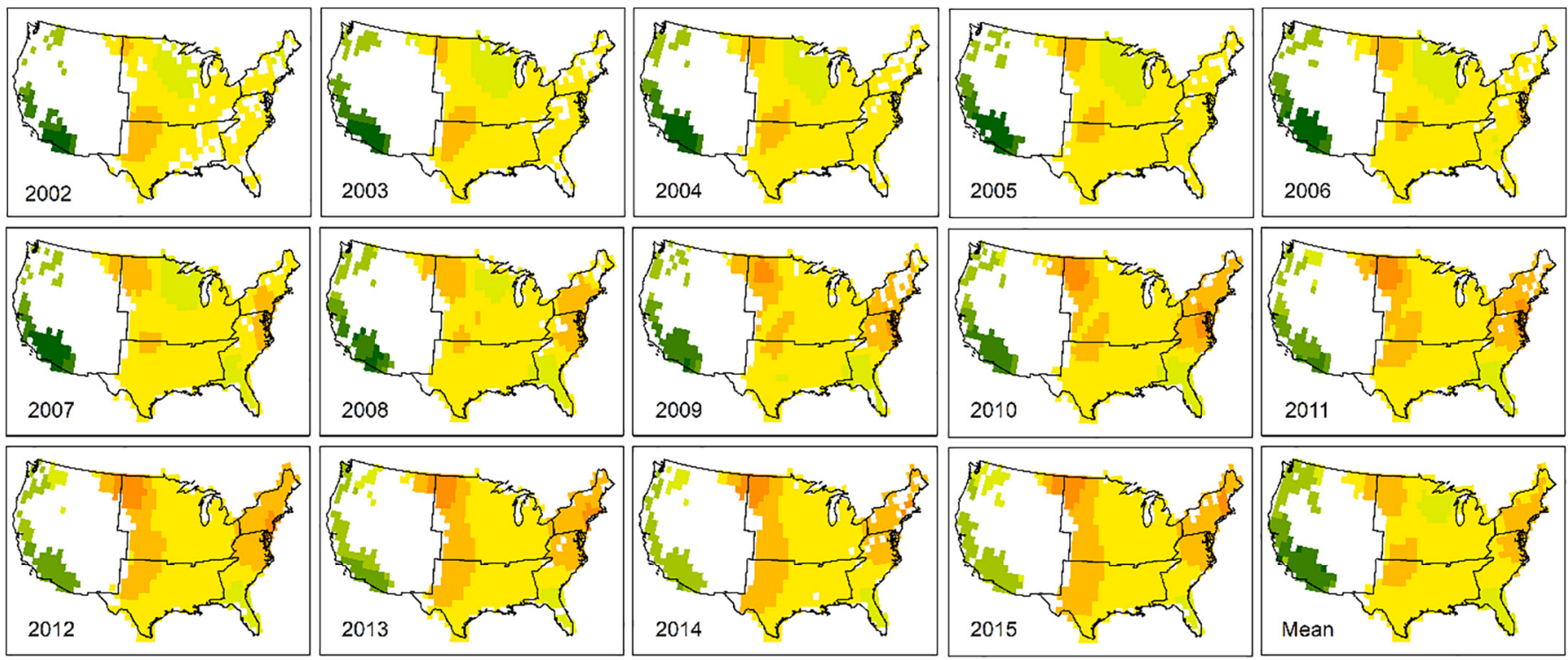

Coefficient

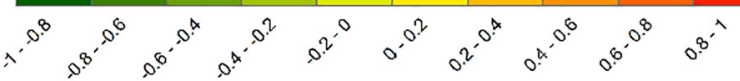

Fig. 5. Spatiotemporal impacts of synthetic $\mathrm{N}$ fertilizer on $\mathrm{NH}_{3}$ concentration for each grid cell during 2002-2015. The last panel is the mean of climatological coefficients. 

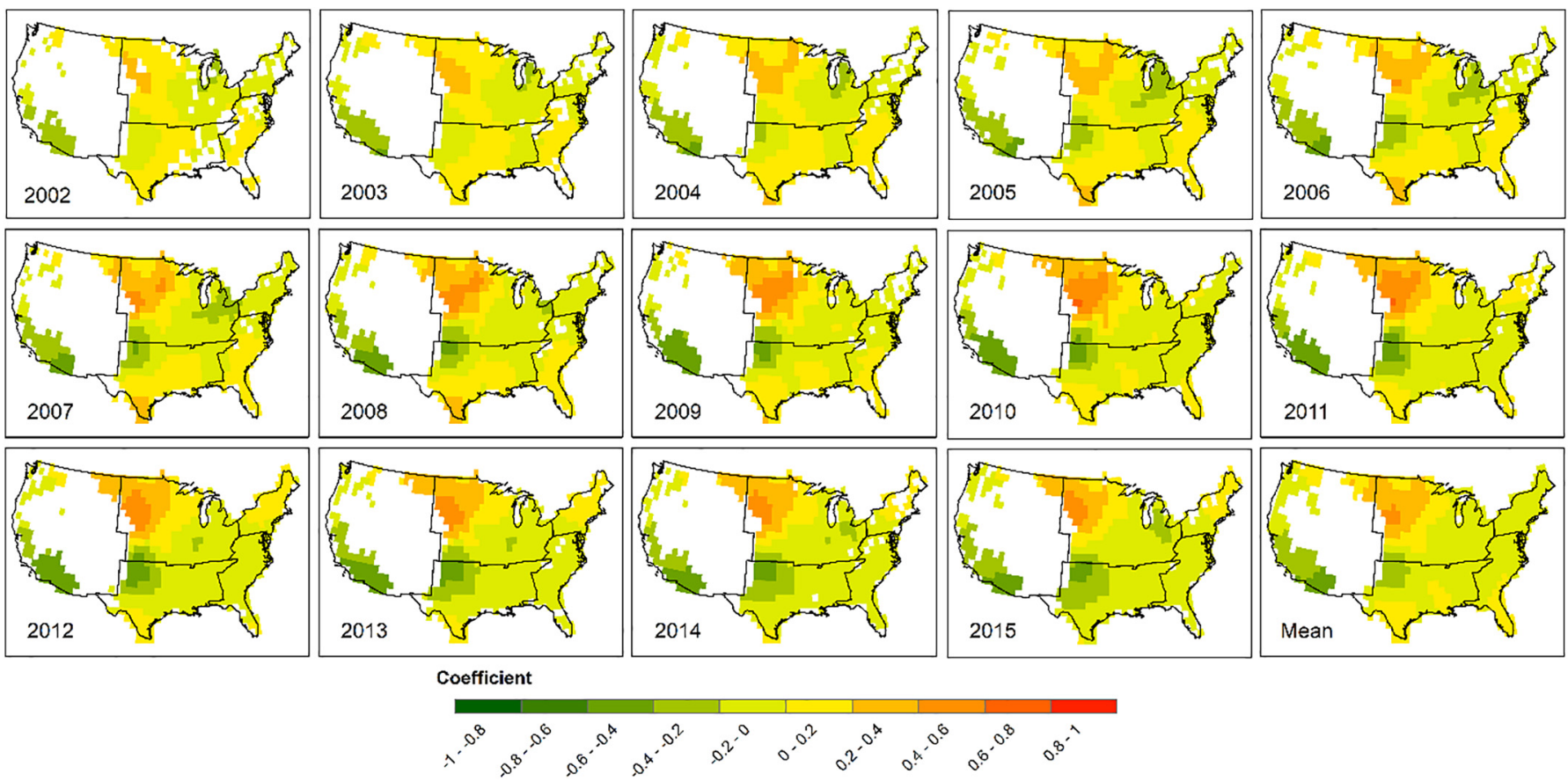

Fig. 6. Spatiotemporal impacts of annual mean temperature on $\mathrm{NH}_{3}$ concentration for each grid cell during 2002-2015. The last panel is the mean of climatological coefficients.

impacts of temperature on $\mathrm{NH}_{3}$ concentrations were positive across central and southern parts of the Mid-South with coefficients ranging from 0 to 0.2 before 2010 . High temperature could be a trigger for increased $\mathrm{NH}_{3}$ emissions from rice and other crop cultivations receiving intensive $\mathrm{N}$ fertilizer and manure applications in these two parts of the Mid-South. Shen et al. (2020a) predicted that the Southern Plains and Delta States (i.e., the Mid-South in this study) would experience a considerable increase in $\mathrm{NH}_{3}$ emissions by 2100 in the RCP8.5 scenario when $\mathrm{N}$ input was fixed at the 2010 level. Consistent with Shen et al. (2020a), our study indicated that this region would possibly become high $\mathrm{NH}_{3}$ concentration hotspots in the context of climate warming. However, this effect gradually diminished in these two parts of the Mid-South (Fig. 6), indicating that contribution of other factors (e.g., manure) increased (Fig. 4). In contrast, there was a persistent weak impact of temperature on $\mathrm{NH}_{3}$ with coefficients ranging from -0.6 to 0 (Fig. 6) in northwestern parts of the MidSouth, while manure and $\mathrm{N}$ fertilizer contributions were relatively higher (Figs. 4-5), indicating that manure and $\mathrm{N}$ fertilizer were the main driving factors for the $\mathrm{NH}_{3}$ variability in the northwestern portions of this region.

Most of the West region lacked data due to high elevation (above the $918 \mathrm{hPa}$ level that data are not shown) or weeks of persistent cloud coverage (Warner et al., 2016), thus leaving only coefficients for northeastern Montana and western coastal areas that include California, Oregon, and Washington (Figs. 4-6). Livestock manure had consistent positive impacts on $\mathrm{NH}_{3}$ concentrations spatiotemporally in the western coastal region, with coefficients larger than 0.8 (Fig. 4 ). High manure influence in this area was largely attributable to considerable $\mathrm{NH}_{3}$ emissions from livestock farming. Furthermore, hot and dry weather conditions might trigger more $\mathrm{NH}_{3}$ gas release from manure. Consistent with our findings, Van Damme et al. (2018) identified several agricultural $\mathrm{NH}_{3}$ emission hotspots in California based on a high resolution map monitored by IASI satellite. Hotspots due to pig farms in Utah were also detected by Van Damme et al. (2018), but were not shown in our study due to missing data. In addition, Li et al. (2017) observed the highest $\mathrm{NH}_{3}$ concentrations near large concentrated animal feeding operations (CAFO) in Colorado when using Radiello passive $\mathrm{NH}_{3}$ samplers. However, this was not captured by NASA AIRS $\mathrm{NH}_{3}$ products (Warner et al., 2017) due to missing data in our study. Winters in the West were getting warmer since 2011 despite summer temperatures remaining similar during 2002-2016 (Fig. 3c). Thus, more $\mathrm{NH}_{3}$ releases from livestock manure during warmer winters possibly contribute to increased annual $\mathrm{NH}_{3}$ concentrations (Amon et al., 2001; Misselbrook et al., 2016; Sutton et al., 2013). The influence of $\mathrm{N}$ fertilizer and temperature on $\mathrm{NH}_{3}$ concentrations had a persistent weak pattern in the western coastal regions; however, both coefficients increased from 2002 to 2015 (Figs. 5-6). This was associated with a continuous increase in fertilizer consumption (Cao et al., 2018) along with temperature (Thornton et al., 2016) in both regions. Similar to our findings for the Northern Great Plains, warming interactions with increased fertilizer consumption led to a continuous increase in $\mathrm{NH}_{3}$ emissions from this region.

Similar to the aforementioned three regions, impacts of livestock manure on $\mathrm{NH}_{3}$ concentrations were positive spatiotemporally in the Southeast and Northeast, with coefficients ranging from 0 to 0.2 (Fig. 4). Although there were numerous hotspots of high livestock manure production in the eastern part of the US from CAFO (Bian et al., 2021), both regions had much smaller manure influences compared to the West. In contrast to California which was dry and hot, the eastern US was hot and humid due to year-round rainfall events. Heavy rainfall can wash livestock manure into nearby riverine systems resulting in less $\mathrm{NH}_{3}$ available for release as $\mathrm{NH}_{3}$ gas (Sinha and Michalak, 2016). For example, there was a measurable effect of CAFO waste manures (typically swine) on water quality in many North Carolina Coastal Plain streams (Harden, 2015). We observed an overall positive pattern of $\mathrm{N}$ fertilizer (coefficients ranging from 0 to 0.6 ) but a weak temperature impact (coefficients ranging from -0.2 to 0 ) in the Northeast and Southeast (except for Florida) during 2002-2015 (Figs. 4-5). Before 2008, the effect of temperature was positive in most regions of the Southeast (coefficients ranging from 0 to 0.2 ), and this effect decreased (coefficients ranging from -0.2 to 0 ) thereafter (Fig. 6).

\subsection{Limitations}

In this study, we examined the impacts of four driving factors on spatiotemporal changes in $\mathrm{NH}_{3}$ concentrations across the US. However, there were several limitations relevant to the driving data and the GTWR model that should be noted. First, the data quality of AIRS $\mathrm{NH}_{3}$ products with a spatial resolution of $1^{\circ} \times 1^{\circ}$ might be too coarse to identify hotspots of $\mathrm{NH}_{3}$ concentrations associated with local farm operations. Van Damme et al. (2018) successfully identified 248 hotspots 
with diameters smaller than $50 \mathrm{~km}$ globally, which served as a significant reference for policy makers to effectively manage $\mathrm{NH}_{3}$ emissions at farm- or local-scales. In addition, there were many missing pixels in the western US that experienced high agricultural activities and had hotspots identified in other studies (Li et al., 2017; Van Damme et al., 2018). The missing data were either due to high elevation (above the $918 \mathrm{hPa}$ level that data are not shown) or persistent cloudy days (Warner et al., 2016). While there were many missing data for the Western US, the AIRS product still successfully provided estimates for key $\mathrm{NH}_{3}$ emission hotspots (i.e., California, Montana, and Washington). Although this was consistent with Van Damme et al. (2018), who used a high-resolution map obtained from IASI satellite observations, they also identified Colorado and Utah as hotspots. Second, Spearman's partial correlation analyses revealed that monthly atmospheric $\mathrm{NH}_{3}$ concentrations were positively correlated with monthly surface temperature in the five US regions (Table 3). However, these strong correlations were not detected between MAT and $\mathrm{NH}_{3}$ concentrations (Table S3). Using annual datasets of temperature might decrease the confidence of GTWR analysis. Once available, future work should take monthly fertilizer and manure datasets into consideration. Last, due to nonstationarity of the model, GTWR might simulate unexpected abrupt changes in coefficients (Huang et al., 2010). For example, the contrasting temperature coefficient signs in 2009 and 2010 for the Southeast indicates a need for further evaluations.

In addition, there are other factors that could be important for explaining changes in $\mathrm{NH}_{3}$ concentrations. The $\mathrm{R}^{2}$ from GTWR was $\sim 0.205$, indicating that three driving factors only explain $\sim 20.5 \%$ of the variability in the dependent variable (i.e., $\mathrm{NH}_{3}$ concentrations). The decline in atmospheric $\mathrm{SO}_{2}$ and $\mathrm{NO}_{x}$ emissions due to U.S. regulations partially contributed to increased $\mathrm{NH}_{3}$ concentrations across the US in recent decades (Van Damme et al., 2020; Warner et al., 2017; Yu et al., 2018). Thus, spatiotemporal changes in $\mathrm{SO}_{2}$ and $\mathrm{NO}_{x}$ emissions should be included in the GTWR model in our future efforts. Although agricultural activities accounted for over $80 \%$ of $\mathrm{NH}_{3}$ emissions (Bouwman et al., 2002), the bi-directional $\mathrm{NH}_{3}$ exchange module indicates that crop canopy tends to absorb some of the released $\mathrm{NH}_{3}$ from fertilized soils (Bash et al., 2013; Nemitz et al., 2001). Thus, crop types and phenology stages could be important factors regulating $\mathrm{NH}_{3}$ releases from synthetic $\mathrm{N}$ fertilizer and manure applications (Xu et al., 2019). In addition, agricultural management strategies (e.g., tillage, irrigation) could affect soil properties (e.g., $\mathrm{pH}$, soil moisture) that further impact $\mathrm{NH}_{3}$ emission patterns (Ma et al., 2021; Xu et al., 2019; Zhan et al., 2021). Failure to account for the above-mentioned factors could introduce large uncertainties when attempting to explain spatiotemporal changes in $\mathrm{NH}_{3}$ concentrations.

\section{Conclusions}

This study is one of the first attempts to investigate the causes of spatial and temporal changes in satellite-derived atmospheric $\mathrm{NH}_{3}$ concentrations based on a GTWR model driven by spatially-explicit datasets of synthetic $\mathrm{N}$ fertilizer application, livestock manure production, and climate factors. Across the US, atmospheric $\mathrm{NH}_{3}$ concentrations have significantly increased by $0.030 \mathrm{ppbv} \mathrm{yr}^{-1}$ between 2002 and 2016. The highest increase was observed in the Midwest, followed by the Mid-South and West regions.

Reasons for these spatiotemporal changes in $\mathrm{NH}_{3}$ concentrations were diverse. Livestock manure and $\mathrm{N}$ fertilizer had consistent positive impacts on $\mathrm{NH}_{3}$ concentrations spatiotemporally in most regions of the Midwest. We observed a continuous rise in the effect of $\mathrm{N}$ fertilizer in northern portions of the Midwest (i.e., Northern Great Plains) largely due to increased fertilizer consumption for spring wheat and corn production. In addition, our results showed that the interactive effect between synthetic $\mathrm{N}$ fertilizer and temperature might stimulate the release of $\mathrm{NH}_{3}$, especially in more vulnerable regions like the Northern Great Plains. In most areas of the Mid-South, high temperature could be a trigger for increased $\mathrm{NH}_{3}$ emissions from rice and other crop cultivations receiving intensive $\mathrm{N}$ fertilizer and manure applications. The high influence of manure in the West was largely attributable to considerable $\mathrm{NH}_{3}$ emissions from livestock farm operations in this region. In addition, hot and dry weather might trigger more $\mathrm{NH}_{3}$ gas release from manure. The Southeast and Northeast depicted much smaller spatiotemporally positive influences of manure compared to the West, presumably due to frequent rainfalls in both regions washing livestock manure into nearby riverine systems resulting in less $\mathrm{NH}_{3}$ available for release.

$\begin{array}{ll}\text { Nomenclature } \\ \mathrm{NH}_{3} & \text { ammonia } \\ \mathrm{N} & \text { nitrogen } \\ \mathrm{NO}_{x} & \text { nitrogen oxides } \\ \text { AMoN } & \text { Atmospheric Deposition Program Ammonia Monitoring } \\ \text { IASI } & \text { Infrared Atmospheric Sounding Interferometer } \\ \text { NADP } & \text { National Atmospheric Deposition Program } \\ \text { GTWR } & \text { geographical and temporal weighted regression } \\ \text { AIRS } & \text { Atmospheric Infrared Sounder } \\ \text { VMRs } & \text { volume mixing ratios } \\ \text { RKT } & \text { Regional Kendall Test } \\ \text { MMT } & \text { mean monthly temperature } \\ \text { MMP } & \text { mean monthly precipitation } \\ \text { WLS } & \text { weighted least squares } \\ \text { AICc } & \text { corrected version of the Akaike information criterion } \\ \text { R } & \text { R-square } \\ \text { OLS } & \text { ordinary least squares } \\ \text { MAT } & \text { mean annual temperatures } \\ \text { MAP } & \text { mean annual precipitation } \\ \text { CMIP6 } & \text { Coupled Model Intercomparison Project Phase 6 } \\ \text { SSPs } & \text { Shared Socioeconomic Pathways } \\ \text { CAFO } & \text { concentrated animal feeding operations }\end{array}$

\section{CRediT authorship contribution statement}

Yaqian He: Methodology, Software, Formal analysis, Investigation, Writing - original draft, Writing - review \& editing. Rongting Xu: Conceptualization, Methodology, Software, Formal analysis, Investigation, Writing - original draft, Writing - review \& editing. Stephen A. Prior: Writing - review \& editing. Di Yang: Visualization, Writing - review \& editing. Anni Yang: Visualization, Writing - review \& editing. Jian Chen: Data curation, Software.

\section{Declaration of competing interest}

The authors declare that they have no known competing financial interests or personal relationships that could have appeared to influence the work reported in this paper.

\section{Acknowledgement}

Y.Q.H. was partially supported by University of Central Arkansas University Research Council grant. R.T.X, Y.Q.H., D.Y., and J.C. were supported by a Microsoft AI for Earth Microsoft Azure Compute Grant.

\section{Appendix A. Supplementary data}

Supplementary data to this article can be found online at https://doi. org/10.1016/j.scitotenv.2021.147899.

\section{References}

Almazroui, M., Islam, M.N., Saeed, F., Saeed, S., Ismail, M., Ehsan, M.A., Diallo, I., O’Brien, E., Ashfaq, M., Martínez-Castro, D., Cavazos, T., Cerezo-Mota, R., Tippett, M.K., Gutowski, W.J., Alfaro, E.J., Hidalgo, H.G., Vichot-Llano, A., Campbell, J.D., Kamil, S., Rashid, I.U., Sylla, M.B., Stephenson, T., Taylor, M., Barlow, M., 2021. Projected changes in temperature and precipitation over the United States, Central America, and the Caribbean in CMIP6 GCMs. Earth Syst. Environ. 5, 1-24. https://doi.org/10.1007/s41748-021-00199-5. 
Amon, B., Amon, T., Boxberger, J., Alt, C., 2001. Emissions of $\mathrm{NH}_{3}, \mathrm{~N}_{2} \mathrm{O}$ and $\mathrm{CH}_{4}$ from dairy cows housed in a farmyard manure tying stall (housing, manure storage, manure spreading). Nutr. Cycl. Agroecosyst. 60, 103-113. https://doi.org/10.1023/A: 1012649028772

Bash, J., Cooter, E., Dennis, R., Walker, J., Pleim, J., 2013. Evaluation of a regional airquality model with bidirectional $\mathrm{NH}_{3}$ exchange coupled to an agroecosystem model. Biogeosciences 10, 1635-1645. https://doi.org/10.5194/bg-10-16352013.

Bauer, S.E., Tsigaridis, K., Miller, R., 2016. Significant atmospheric aerosol pollution caused by world food cultivation. Geophys. Res. Lett. 43, 5394-5400. https://doi.org/ 10.1002/2016GL068354.

Bian, Z., Tian, H., Yang, Q., Xu, R., Pan, S., Zhang, B., 2021. Production and application of manure nitrogen and phosphorus in the United States since 1860. Earth Syst. Sci. Data 13, 515-527. https://doi.org/10.5194/essd-13-515-2021.

Bouwman, A., Boumans, L., Batjes, N., 2002. Estimation of global $\mathrm{NH}_{3}$ volatilization loss from synthetic fertilizers and animal manure applied to arable lands and grasslands. Global Biogeochem. Cy. 16, 1024. https://doi.org/10.1029/2000GB001389.

Cao, P., Lu, C., Yu, Z., 2018. Historical nitrogen fertilizer use in agricultural ecosystems of the contiguous United States during 1850-2015: application rate, timing, and fertilizer types. Earth Syst. Sci. Data 10, 969-984. https://doi.org/10.5194/essd-10-9692018.

Cao, P., Lu, C., Zhang, J., Khadilkar, A., 2020. Northwestward cropland expansion and growing urea-based fertilizer use enhanced $\mathrm{NH}_{3}$ emission loss in the contiguous United States. Atmos. Chem. Phys. 20, 11907-11922. https://doi.org/10.5194/acp20-11907-2020.

Chu, H.-J., Huang, B., Lin, C.-Y., 2015. Modeling the spatio-temporal heterogeneity in the PM10-PM2.5 relationship. Atmos. Environ. 102, 176-182. https://doi.org/10.1016/j. atmosenv.2014.11.062.

Clark, C.M., Tilman, D., 2008. Loss of plant species after chronic low-level nitrogen deposition to prairie grasslands. Nature 451, 712-715. https://doi.org/10.1038/ nature06503.

Cullen, D.W., Guida, V., 2021. Use of geographically weighted regression to investigate spatial non-stationary environmental effects on the distributions of black sea bass (Centropristis striata) and scup (Stenotomus chrysops) in the Mid-Atlantic Bight, USA. Fish. Res. 234, 105795. https://doi.org/10.1016/j.fishres.2020.105795.

Davidson, E.A., David, M.B., Galloway, J.N., Goodale, C.L., Haeuber, R., Harrison, J.A., Howarth, R.W., Jaynes, D.B., Lowrance, R.R., Thomas, N.B., Peel, J.L., Pinder, R.W., Porter, E., Snyder, C.S., Townsend, A.R., Ward, M.H., 2011. Excess nitrogen in the US environment: trends, risks, and solutions. Iss. Ecol. 15, 1-16. http://www.esa.org/ esa/wp-content/uploads/2013/03/issuesinecology15.pdf.

Du, E., 2016. Rise and fall of nitrogen deposition in the United States. Proc. Natl. Acad. Sci. U. S. A. 113, E3594-E3595. https://doi.org/10.1073/pnas.1607543113.

Du, E., de Vries, W., Galloway, J.N., Hu, X., Fang, J., 2014. Changes in wet nitrogen deposition in the United States between 1985 and 2012. Environ. Res. Lett. 9, 095004. https://doi.org/10.1088/1748-9326/9/9/095004.

Fotheringham, A.S., Crespo, R., Yao, J., 2015. Geographical and temporal weighted regression (GTWR). Geogr. Anal. 47, 431-452. https://doi.org/10.1111/gean.12071.

Fowler, D., Steadman, C.E., Stevenson, D., Coyle, M., Rees, R.M., Skiba, U., Sutton, M., Cape, J., Dore, A., Vieno, M., 2015. Effects of global change during the 21st century on the nitrogen cycle. Atmos. Chem. Phys. 15, 13849-13893. https://doi.org/10.5194/acp15-13849-2015.

Griffis, T.J., Hu, C., Baker, J.M., Wood, J.D., Millet, D.B., Erickson, M., Yu, Z., Deventer, M.J., Winker, C., Chen, Z., 2019. Tall tower ammonia observations and emission estimates in the US Midwest. J. Geophys. Res.-Biogeo. 124, 3432-3447. https://doi.org/10.1029/ 2019JG005172.

Harden, S.L., 2015. Surface-Water Quality in Agricultural Watersheds of the North Carolina Coastal Plain Associated with Concentrated Animal Feeding Operations. Scientific Investigations Report, Reston, VA, p. 70. http://pubs.er.usgs.gov/publication/ sir20155080.

Hong, Z., Mei, C., Wang, H., Du, W., 2021. Spatiotemporal effects of climate factors on childhood hand, foot, and mouth disease: a case study using mixed geographically and temporally weighted regression models. Int. J. Geogr. Inf. Sci., 1-23 https://doi. org/10.1080/13658816.2021.1882681.

Hou, W., Gao, J., Wu, S., Dai, E., 2015. Interannual variations in growing-season NDVI and its correlation with climate variables in the southwestern karst region of China. Remote Sens. 7, 11105-11124. https://doi.org/10.3390/rs70911105.

Hu, Q., Woodruff, C., Mudrick, S.E., 1998. Interdecadal variations of annual precipitation in the Central United States. B. Am. Meteorol. Soc. 79, 221-230. https://doi.org/10.1175/ 1520-0477(1998)079<0221:IVOAPI > 2.0.CO;2.

Hu, C., Griffis, T.J., Baker, J.M., Wood, J.D., Millet, D.B., Yu, Z., Lee, X., 2020. Modeling the sources and transport processes during extreme ammonia episodes in the US Corn Belt. J. Geophys. Res.-Atmos. 125, e2019JD031207. https://doi.org/10.1029/ 2019JD031207.

Hu, C., Griffis, T.J., Frie, A., Baker, J.M., Wood, J.D., Millet, D.B., Yu, Z., Yu, X., Czarnetzki, A.C., 2021. A multiyear constraint on ammonia emissions and deposition within the US corn belt. Geophys. Res. Lett. 48, e2020GL090865. https://doi.org/10.1029/ 2020GL090865.

Huang, B., Wu, B., Barry, M., 2010. Geographically and temporally weighted regression for modeling spatio-temporal variation in house prices. Int. J. Geogr. Inf. Sci. 24, 383-401. https://doi.org/10.1080/13658810802672469.

Hurvich, C.M., Simonoff, J.S., Tsai, C.L., 1998. Smoothing parameter selection in nonparametric regression using an improved Akaike information criterion. J. Roy. Stat. Soc. B. 60, 271-293. https://doi.org/10.1111/1467-9868.00125.

Karl, T.R., Knight, R.W., 1998. Secular trends of precipitation amount, frequency, and intensity in the United States. B. Am. Meteorol. Soc. 79, 231-242. https://doi.org/ 10.1175/1520-0477(1998)079<0231:STOPAF>2.0.CO;2.
Kim, S., 2015. ppcor: an R package for a fast calculation to semi-partial correlation coefficients. Commun. Stat. Appl. Meth. 22, 665-674. https://doi.org/10.5351/CSAM.2015.22.6.665.

Li, Y., Thompson, T.M., Damme, M.V., Chen, X., Benedict, K.B., Shao, Y., Day, D., Boris, A. Sullivan, A.P., Ham, J., 2017. Temporal and spatial variability of ammonia in urban and agricultural regions of northern Colorado, United States. Atmos. Chem. Phys. 17, 6197-6213. https://doi.org/10.5194/acp-17-6197-2017.

Ma, R., Zou, J., Han, Z., Yu, K., Wu, S., Li, Z., Liu, S., Niu, S., Horwath, W.R., Zhu-Barker, X. 2021. Global soil-derived ammonia emissions from agricultural nitrogen fertilizer application: a refinement based on regional and crop-specific emission factors. Glob. Chang. Biol. 27, 855-867. https://doi.org/10.1111/gcb.15437.

Marchetto, A., Rogora, M., Arisci, S., 2013. Trend analysis of atmospheric deposition data: a comparison of statistical approaches. Atmos. Environ. 64, 95-102. https://doi.org/ 10.1016/j.atmosenv.2012.08.020.

Misselbrook, T., Hunt, J., Perazzolo, F., Provolo, G., 2016. Greenhouse gas and ammonia emissions from slurry storage: impacts of temperature and potential mitigation through covering (pig slurry) or acidification (cattle slurry). J. Environ. Qual. 45, 1520-1530. https://doi.org/10.2134/jeq2015.12.0618.

Nair, A.A., Yu, F., Luo, G., 2019. Spatioseasonal variations of atmospheric ammonia concentrations over the United States: comprehensive model-observation comparison. J. Geophysical Res.-Atmos. 124, 6571-6582. https://doi.org/10.1029/2018JD030057.

Nemitz, E., Milford, C., Sutton, M.A., 2001. A two-layer canopy compensation point model for describing bi-directional biosphere-atmosphere exchange of ammonia. Q. J. R. Meteorol. Soc. 127, 815-833. https://doi.org/10.1002/qj.49712757306.

Qu, S., Hu, S., Li, W., Zhang, C., Li, Q., Wang, H., 2020. Temporal variation in the effects of impact factors on residential land prices. Appl. Geogr. 114, 102124. https://doi.org/ 10.1016/j.apgeog.2019.102124.

Shen, H., Chen, Y., Hu, Y., Ran, L., Lam, S.K., Pavur, G.K., Zhou, F., Pleim, J.E., Russell, A.G., 2020a. Intense warming will significantly increase cropland ammonia volatilization threatening food security and ecosystem health. One Earth 3, 126-134. https://doi. org/10.1016/j.oneear.2020.06.015.

Shen, X., Zhou, Y., Jin, S., Wang, D., 2020b. Spatiotemporal influence of land use and household properties on automobile travel demand. Transport. Res. D.-Tr. E. 84, 102359. https://doi.org/10.1016/j.trd.2020.102359.

Shephard, M., Cady-Pereira, K., Luo, M., Henze, D., Pinder, R., Walker, J., Rinsland, C., Bash, J., Zhu, L., Payne, V., 2011. TES ammonia retrieval strategy and global observations of the spatial and seasonal variability of ammonia. Atmos. Chem. Phys. 11, 10743-10763. https://doi.org/10.5194/acp-11-10743-2011.

Shephard, M.W., Dammers, E., Cady-Pereira, K.E., Kharol, S.K., Thompson, J., Gainariu-Matz, Y., Zhang, J., McLinden, C.A., Kovachik, A., Moran, M., 2020. Ammonia measurements from space with the Cross-track Infrared Sounder: characteristics and applications. Atmos. Chem. Phys. 20, 2277-2302. https://doi.org/10.5194/acp-20-2277-2020.

Sinha, E., Michalak, A.M., 2016. Precipitation dominates interannual variability of riverine nitrogen loading across the continental United States. Environ. Sci. Technol. 50, 12874-12884. https://doi.org/10.1021/acs.est.6b04455.

Stephen, K., Aneja, V.P., 2008. Trends in agricultural ammonia emissions and ammonium concentrations in precipitation over the southeast and Midwest United States. Atmos. Environ. 42, 3238-3252. https://doi.org/10.1016/j.atmosenv.2007.05.062.

Sutton, M.A., Reis, S., Riddick, S.N., Dragosits, U., Nemitz, E., Theobald, M.R., Tang, Y.S. Braban, C.F., Vieno, M., Dore, A.J., 2013. Towards a climate-dependent paradigm of ammonia emission and deposition. Philos. T. R. Soc. B. 368, 20130166. https://doi. org/10.1098/rstb.2013.0166.

Thornton, M.M., Thornton, P.E., Wei, Y., Mayer, B.W., Cook, R.B., Vose, R.S., 2016. Daymet: Monthly Climate Summaries on a 1-km grid for North America, Version 3. ORNL Distributed Active Archive Center https://doi.org/10.3334/ORNLDAAC/1345.

Tian, H., Xu, R., Canadell, J.G., Thompson, R.L., Winiwarter, W., Suntharalingam, P., Davidson, E.A., Ciais, P., Jackson, R.B., Janssens-Maenhout, G., Prather, M.J., Regnier, P., Pan, N., Pan, S., Peters, G.P., Shi, H., Tubiello, F.N., Zaehle, S., Zhou, F., Arneth, A., Battaglia, G., Berthet, S., Bopp, L., Bouwman, A.F., Buitenhuis, E.T., Chang, J., Chipperfield, M.P., Dangal, S.R.S., Dlugokencky, E., Elkins, J.W., Eyre, B.D., Fu, B., Hall, B., Ito, A., Joos, F., Krummel, P.B., Landolfi, A., Laruelle, G.G., Lauerwald, R., Li, W., Lienert, S., Maavara, T., MacLeod, M., Millet, D.B., Olin, S., Patra, P.K., Prinn, R.G., Raymond, P.A., Ruiz, D.J., van der Werf, G.R., Vuichard, N., Wang, J., Weiss, R.F., Wells, K.C., Wilson, C., Yang, J., Yao, Y., 2020. A comprehensive quantification of global nitrous oxide sources and sinks. Nature 586, 248-256. https://doi.org/10.1038/ S41586-020-2780-0.

USDA-ERS, 2013. Fertilizer use and price. U.S. Department of Agriculture-Economic Research Servicehttps://www.ers.usda.gov/data-products/fertilizer-use-and-price. aspx.

Van Damme, M., Clarisse, L., Whitburn, S., Hadji-Lazaro, J., Hurtmans, D., Clerbaux, C. Coheur, P.-F., 2018. Industrial and agricultural ammonia point sources exposed. Nature 564, 99-103. https://doi.org/10.1038/S41586-018-0747-1.

Van Damme, M., Clarisse, L., Franco, B., Sutton, M.A., Erisman, J.W., Kruit, R.W., van Zanten, M., Whitburn, S., Hadji-Lazaro, J., Hurtmans, D., 2020. Global, regional and national trends of atmospheric ammonia derived from a decadal (2008-2018) satellite record. Environ. Res. Lett. https://doi.org/10.1088/1748-9326/abd5e0.

Wang, R., Guo, X., Pan, D., Kelly, J.T., Bash, J.O., Sun, K., Paulot, F., Clarisse, L., Van Damme, M., Whitburn, S., 2021. Monthly patterns of ammonia over the contiguous United States at $2 \mathrm{~km}$ resolution. Geophys. Res. Lett. 48, e2020GL090579. https://doi.org/ 10.1029/2020GL090579.

Warner, J.X., Wei, Z., Strow, L.L., Dickerson, R.R., Nowak, J.B., 2016. The global tropospheric ammonia distribution as seen in the 13-year AIRS measurement record. Atmos. Chem. Phys. 16, 5467-5479. https://doi.org/10.5194/acp-16-5467-2016.

Warner, J., Dickerson, R., Wei, Z., Strow, L.L., Wang, Y., Liang, Q., 2017. Increased atmospheric ammonia over the world's major agricultural areas detected from space. Geophys. Res. Lett. 44, 2875-2884. https://doi.org/10.1002/2016GL072305. 
Wu, C., Ren, F., Hu, W., Du, Q., 2019. Multiscale geographically and temporally weighted regression: exploring the spatiotemporal determinants of housing prices. Int. J. Geogr. Inf. Sci. 33, 489-511. https://doi.org/10.1080/13658816.2018.1545158.

Xu, R., Pan, S., Chen, J., Chen, G., Yang, J., Dangal, S., Shepard, J., Tian, H., 2018. Half-century ammonia emissions from agricultural systems in southern Asia: magnitude, spatiotemporal patterns, and implications for human health. GeoHealth 2, 40-53. https:// doi.org/10.1002/2017GH000098.

Xu, R., Tian, H., Pan, S., Prior, S.A., Feng, Y., Batchelor, W.D., Chen, J., Yang, J., 2019. Global ammonia emissions from synthetic nitrogen fertilizer applications in agricultural systems: empirical and process-based estimates and uncertainty. Glob. Chang. Biol. 25, 314-326. https://doi.org/10.1111/gcb.14499.

Yu, F., Nair, A.A., Luo, G., 2018. Long-term trend of gaseous ammonia over the United States: modeling and comparison with observations. J. Geophys. Res.-Atmos. 123, 8315-8325. https://doi.org/10.1029/2018JD028412.

Zhan, X., Adalibieke, W., Cui, X., Winiwarter, W., Reis, S., Zhang, L., Bai, Z., Wang, Q., Huang, W., Zhou, F., 2021. Improved estimates of ammonia emissions from global croplands. Environ. Sci. Technol. 55, 1329-1338. https://doi.org/10.1021/acs. est.0c05149. 